\title{
The Development of Hots-based Student Worksheets with Discovery Learning Model
}

\author{
Katon Agung Ramadhan', Suparman ${ }^{1, *}$, Yahya Hairun ${ }^{2}$, Asmar Bani $^{2}$ \\ ${ }^{1}$ Department of Mathematics Education, Faculty of Teacher Training and Education, Ahmad Dahlan University, Indonesia \\ ${ }^{2}$ Department of Mathematics Education, Faculty of Teacher Training and Education, Khairun University, Indonesia
}

Received December 5, 2019; Revised January 7, 2020; Accepted February 3, 2020

Copyright $\bigcirc 2020$ by authors, all rights reserved. Authors agree that this article remains permanently open access under the terms of the Creative Commons Attribution License 4.0 International License

\begin{abstract}
Higher-Order Thinking Skills (HOTS) is one of the important skills that every student has to master it in the 21 st century. Discovery learning is a learning model that can be used to train HOTS in the learning process. The purpose of this research is to develop HOTS-based student worksheets with a discovery learning model for trigonometry subjects in the tenth grade and to assess it based on the media assessment, material assessment, and the practical assessment. The subjects of this research are the researcher and some validators, while the objects of this research are 33 students, which consist of X IPA 1 students of SMA Negeri 1 Turi and X IPA students of SMA Islam 3 Sleman 2018/2019 academic year. The result shows that the criteria of the developed student worksheets are very feasible based on the media assessment, material assessment, and practical assessment. The developed student worksheets have an average score of 4.49 from three media validators, 4.39 from three material validators, and 4.33 from 33 students who become the respondent. It explains that the developed student worksheets can be used as an alternative student worksheet during the learning process in the class, which can train the student's HOTS.
\end{abstract}

Keywords Higher-order Thinking Skills, Student Worksheets, Discovery Learning

\section{Introduction}

Thinking is a term that is used to describe intellectual. Thinking process cannot be observed directly, but it can be identified by the act, which reflects the thinking process, and it is called cognitive skill [1]. There are two thinking skills, and they are lower-order thinking skills (LOTS) and higher-order thinking skills (HOTS). HOTS is harder to do than LOTS, but it can be identified when it occurs. HOTS can be identified by observing its characteristics, such as non-algorithmic, multiple criteria application, involve various complex solution, self-regulation, and sometimes involve uncertainty [2]. One of the success indicators to encourage human resources in education is the good indicator of student's higher-order thinking skills because learning purpose in the $21^{\text {st }}$ century is to develop and enhance student's higher-order thinking skills [3]. Based on the previous statement, we know that HOTS is very important and should be learned to students.

Smith in [4] states that HOTS is a thinking process based on various skills, such as skills to analysis, synthesis, compare, generalize, interpret, assess, and inductive and deductive reasoning, which is used to solve a problem. HOTS is commonly described as critical thinking, such as reasoning, reflective thinking, which is used to determine something believed/done [5]. King et al. in [5] state that HOTS consists of active-creative thinking when students face unusual, uncertainty, and dilemma problems. Furthermore, Krulik \& Rudnick in [3] explains that critical thinking and creative thinking are HOTS, whereas recall and basic skills are LOTS. Based on that expert's statement, HOTS is a complex thinking skill that consists of critical thinking and creative thinking.

HOTS is assessed by using a particular instrument in the learning process. The teacher may use compatible assessments to evaluate student's HOTS in the learning process. The purpose of the evaluation is to help the teacher to identify the student's HOTS level. The assessment should be driven to appreciate and use HOTS instead of concept mastering [6]. Thinking can be trained and developed through practice [6]. It shows that thinking can be taught. Considering that all of us were born with thinking and the limitation of each individual's intelligence capacity becomes the reason that critical thinking needs to be developed so that every student can achieve their maximum ability in critical thinking [6]. It 
explains that thinking ability can be developed in particular ways through practical, so do HOTS. Teacher competence in measuring and training HOTS become important things to develop student's HOTS. They can integrate any learning models or teaching aid which can be used to develop HOTS.

Apino [3] states that HOTS can be trained and enhanced through instructional design. The teacher can train the student's HOTS by giving them an unusual problem and train them to ask "why" and "how" in the learning process. Furthermore, Apino suggests adapting TIMSS and PISA problem to make an unusual problem for students. Verdina [7] states that the most uses teaching aid in the learning process is student worksheets. Student worksheets can be used to develop creative thinking, enhance student's activity in the learning process, and as teacher evaluator media. Student worksheets are developed to achieve particular learning purposes based on prevailing basic competencies. The purpose flexibility of student worksheets implementation becomes the reason it is the most used media. The teacher can use it to train and develop HOTS.

Student worksheets may be integrated with various learning approaches and models. The use of learning approach and model in student worksheets based on the learning purpose. There are many learning models which able to train HOTS, and one of them is discovery learning. It is similar to Yuliani's statement [8], which states that discovery learning is effective and has a positive impact on a student's conceptual understanding and critical thinking. The discovery learning model is a learning model that is served to students to guide them to find a new concept. Students are expected to be able to actively discover new knowledge like creating a hypothesis, estimating, and trying beneath the teacher's help.

Discovery learning has several syntaxes. They are: (1) stimulation, the syntax where teacher gives a non-routine problem to students to stimulate them and exploring relevant material, (2) problem statement, the syntax where the students identify the problem of making a hypothesis through observing, interviewing, and etc, (3) data collecting, the syntax where the students interpret the received data, (4) data verification, the syntax where the students verify the received data, and (5) generalization, the syntax where the students generalize a new concept and principle based on the previous result [9].

HOTS is an important skill for students in this era. This skill must be taught to students in the learning process. Ideally, students should have HOTS, or their HOTS level is high, but the facts show that HOTS level of Indonesian students is low. This is based on the results of the TIMSS score in 2015. It shows that the cognitive scores of Indonesian students were below the international average. The lack of HOTS-based media and learning models is a factor in the lowness of Indonesian student's HOTS, so the question of this research is "how to develop HOTS-based student worksheets with discovery learning models in $10^{\text {th }}$-grade high school students?". The purpose of this research is to develop and test the eligibility of HOTS-based student worksheets with the discovery learning model in $10^{\text {th }}$-grade high school students.

\section{Research Method}

As in [10-14], this research is R\&D kind, which uses a modified 4D development model. The 4D development model has four procedures, they are: (1) define, (2) design, (3) develop, and (4) disseminate [15]. The researcher adapts those development procedures and adjusts it depends on the research need, time, and resources. The research objects are X IPA 1 SMA Negeri 1 Turi students and X IPA SMA Islam 3 Sleman students.

Define is the first procedure to receive precursor data. The researcher does some activity before developing the product, such as analyzing the needs for the product in the school, analyzing the student's thinking level and corresponding curriculum, the learning subject, and formulating the learning purpose. The data of this procedure is qualitative, which is received from student observation in class and interviewing the teacher.

Design is the procedure where the researcher designs the product based on the analysis in the defined procedure. Researcher designs product display, the content, component layout in the product, and the embellishment in the product. The design based on the product framework. Besides, the researcher also designs the product assessment instrument.

Develop is the procedure to develop the product based on the designed draft. The researcher develops the product draft until it becomes a final product. The researcher does some activity on this procedure, such as develop the product, validate the product to experts, and do the product revision. The validating process is one of the important things to create a final product. The validator will be the next material revision. The product revision includes component addition in the product, information addition, and miss concept correction. The validated product will be assessed by the experts by using the instrument, which is designed by the researcher. The researcher uses a questionnaire method to collect quantitative data from experts. The questionnaire is a Likert scale closed-questionnaire kind and consists of a mathematic subject questionnaire and media questionnaire. The product assessment purpose is to determine product eligibility based on the mathematics subject and media aspect.

Disseminate is the procedure for testing the product eligibility at school. The researcher distributes the product to students as the research object to assess the eligibility level. The researcher uses the questionnaire method to collect quantitative data from the student's assessment as the research object. The questionnaire is a closed Likert scale questionnaire. 
The quantitative data in this research is analyzed by using descriptive statistic, which means the data average of each aspect should be calculated and described based on the specific eligibility level. As for the eligibility level defined by the expert, it can be seen in the Table 1:

Table 1. Assessment Score Conversion Scale 1-5

\begin{tabular}{|c|c|c|}
\hline Score Interval & Score Average & Criteria \\
\hline$\overline{\mathrm{X}}>\overline{\mathrm{X}}_{\mathrm{i}}+1.8\left(\mathrm{Sb}_{\mathrm{i}}\right)$ & $\overline{\mathrm{X}}>4.2$ & Very Feasible \\
\hline$\overline{\mathrm{X}}_{\mathrm{i}}+0.6\left(\mathrm{Sb}_{\mathrm{i}}\right)<\overline{\mathrm{X}} \leq \overline{\mathrm{X}}_{\mathrm{i}}+1.8\left(\mathrm{Sb}_{\mathrm{i}}\right)$ & $3.4<\overline{\mathrm{X}} \leq 4.2$ & Feasible \\
\hline$\overline{\mathrm{X}}_{\mathrm{i}}-0.6\left(\mathrm{Sb}_{\mathrm{i}}\right)<\overline{\mathrm{X}} \leq \overline{\mathrm{X}}_{\mathrm{i}}+0.6\left(\mathrm{Sb}_{\mathrm{i}}\right)$ & $2.6<\overline{\mathrm{X}} \leq 3,4$ & Enough \\
\hline$\overline{\mathrm{X}}_{\mathrm{i}}-1.8\left(\mathrm{Sb}_{\mathrm{i}}\right)<\overline{\mathrm{X}} \leq \overline{\mathrm{X}}_{\mathrm{i}}-0.6\left(\mathrm{Sb}_{\mathrm{i}}\right)$ & $1.8<\overline{\mathrm{X}} \leq 2.6$ & Infeasible \\
\hline$\overline{\mathrm{X}} \leq \overline{\mathrm{X}}_{\mathrm{i}}-1.8\left(\mathrm{Sb}_{\mathrm{i}}\right)$ & $\overline{\mathrm{X}} \leq 1.8$ & Infeasible At All \\
\hline
\end{tabular}

Information:

$\overline{\mathrm{X}}$ : Average score of each component

$\overline{\mathrm{X}}_{\mathrm{i}}$ : Ideal average

$=\frac{1}{2}$ (maximal score + minimal score $)$

$\mathrm{Sb}_{\mathrm{i}}$ : Ideal standard deviation

$=\frac{1}{6}$ (maximal score - minimal score $)$

\section{Result and Discussion}

The HOTS-based student worksheets with discovery learning in the $10^{\text {th }}$-grade high school students are designed by adapting the 4D development model. The 4D development model has four procedures, and they are: define, design, develop, and disseminate. This research does not apply to the whole procedure. The researcher only applies the development procedure until the dissemination procedure. The results of every procedure will be explicitly explained.

Define is the first procedure of the 4D development model. On the worksheet's development context, define contains the needs analysis, student character analysis, curriculum analysis, material analysis, and formulating the purpose. The researcher does some activities on this procedure, such as (1) the analysis of student worksheet's needs, (2) student character analysis, (3) curriculum analysis, (4) material analysis, and (5) formulating the purpose. The results of this procedure are: (1) student's problems in the school are lacking numerical ability, lacking mathematical problem-solving ability, and lacking self-regulation, (2) those problems happen every year, (3) school applies the 2013 curriculum, (4) the main teaching aid which is used by the teacher is book from education minister, (5) the side teaching aid which is used by the teacher is student worksheets from education minister or from the teacher itself, (6) teacher assumes that the students still have a problem to solve the problem related to sine and cosine rule and trigonometry function.
Design is the procedure when the researcher designs the student worksheets. The design of development student worksheets based on the previous procedure data. The researcher does some activities on this procedure, such as (1) designing the draft of development student worksheets, (2) designing the framework of development student worksheets, (3) designing the content and layout of student worksheets, and (4) designing the assessor instrument of development student worksheets. The results are the framework and the assessor instrument of development student worksheets.

Develop is the procedure when the researcher develops the previous design. On this procedure, student worksheets development is repeated based on the revision until it becomes final and complete that can be tested in the school. The advises and comments from the validator becomes the revision material. The revise is repeated until it is the final student worksheet.

The final step of the $4 \mathrm{D}$ development procedure is disseminating. There are three activities on this procedure, they are validation testing, packaging, and diffusion, and adaptation, yet the researcher only adapts the first activity. On the validation testing, the researcher distributes the development student worksheets to research objects and asks them to assess the eligibility based on the questionnaire, which is designed by the researcher. That activity's purpose is to measure the product eligibility level. The development of the student worksheets design framework can be seen in Figure 1: 


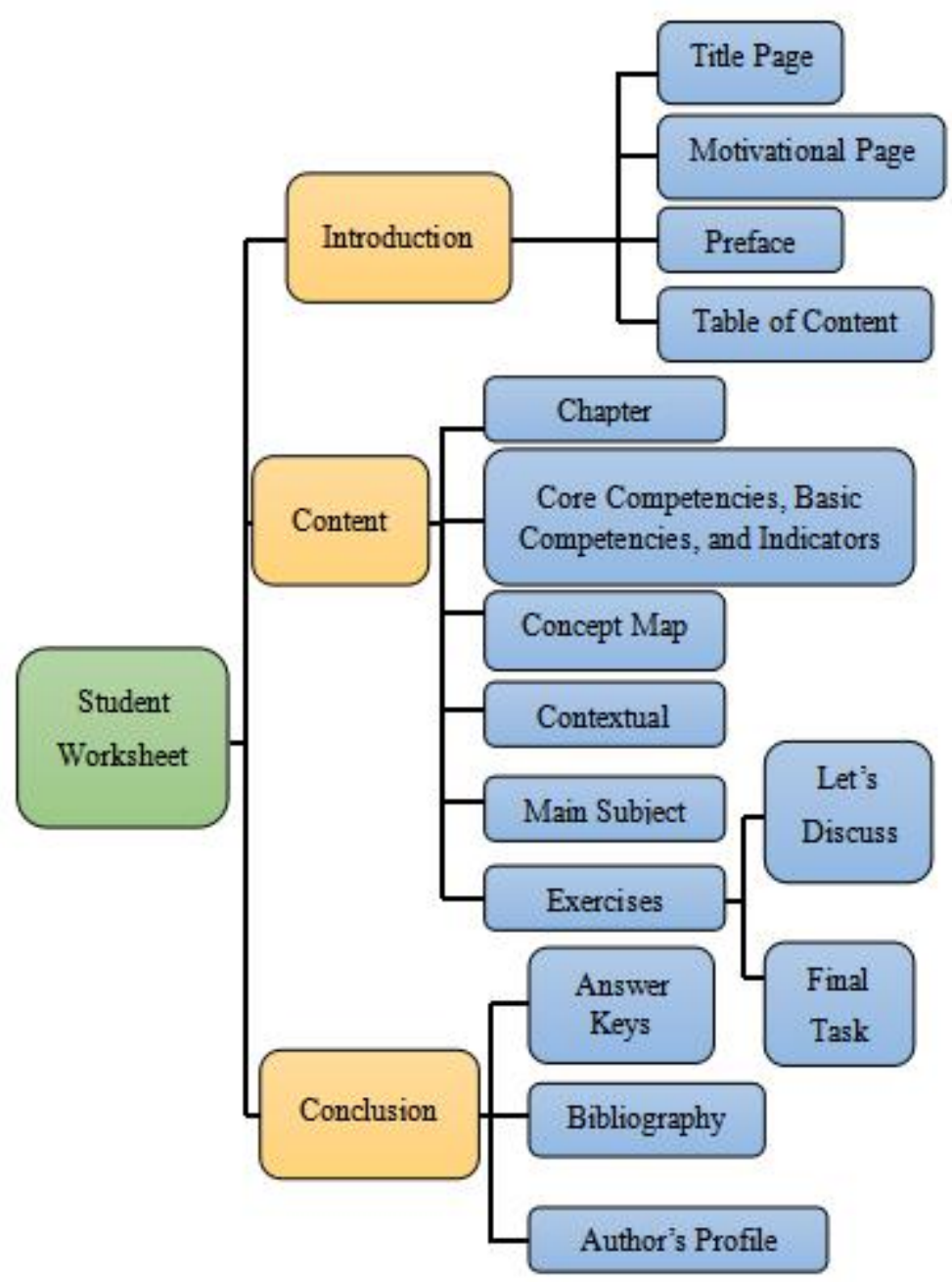

Figure 1. The Development Student Worksheets Design Framework

The final results from the 4D development model are the final and complete student worksheets and student worksheets assessment data. Student worksheets assessment divided into two assessments; they are eligibility and product practical assessment. The product eligibility level is analyzed from the material and media aspects. Material and media validators are the mathematic education lecturers of Universitas Ahmad Dahlan and teachers of SMA Negeri 1 Turi and SMA Islam 3 Sleman. The data is analyzed for each aspect and every validator's assessment. The data analysis is given in Tables 2 - 5:
Table 2. Results of Data Analysis Each Aspect of Development Student Worksheets from Media Aspect

\begin{tabular}{cccc}
\hline No. & Aspect & $\begin{array}{c}\text { Score } \\
\text { Average }\end{array}$ & Criteria \\
\hline 1. & Compatibility & 4.48 & Very Feasible \\
2. & Completeness & 4.17 & Feasible \\
3. & $\begin{array}{c}\text { Exactness and } \\
\text { Orderliness }\end{array}$ & 4.17 & Feasible \\
4. & $\begin{array}{c}\text { Practicability and } \\
\text { Interactivity }\end{array}$ & 4.50 & Very Feasible \\
5. & $\begin{array}{c}\text { The Quality of } \\
\text { Teaching Aid }\end{array}$ & 4.83 & Very Feasible \\
\hline & Score Average & 4.43 & Very Feasible \\
\hline
\end{tabular}


Table 3. Results of Data Analysis of Development Student Worksheets from Each Media Validator

\begin{tabular}{cccc}
\hline No. & Validator & $\begin{array}{c}\text { Score } \\
\text { Average }\end{array}$ & Criteria \\
\hline 1. & Syariful Fahmi & 4.76 & Very Feasible \\
2. & Retno Kuntari & 4.35 & Very Feasible \\
3. & Heri Permana Sakti & 4.35 & Very Feasible \\
\hline & Score Average & 4.49 & Very Feasible \\
\hline
\end{tabular}

Table 4. Results of Data Analysis Each Aspect of Development Student Worksheets from Mathematics Subject Aspect

\begin{tabular}{cccc}
\hline No. & Aspect & $\begin{array}{c}\text { Score } \\
\text { Average }\end{array}$ & Criteria \\
\hline 1. & The Compatibility and & 4.18 & Feasible \\
2. & Ease & 4.33 & Very Feasible \\
3. & Conspicuousness & 4.14 & Feasible \\
4. & Clarity & 4.23 & Very Feasible \\
5. & $\begin{array}{c}\text { Completeness } \\
\text { Exactibility and }\end{array}$ & 3.90 & Feasible \\
6. & $\begin{array}{c}\text { Communicative and } \\
\text { Motivation }\end{array}$ & 4.29 & Very Feasible \\
\hline & Score Average & 4.18 & Feasible \\
\hline
\end{tabular}

Table 5. Data Analysis Results of Development Student Worksheets from Each Mathematics Subject Validator

\begin{tabular}{cccc}
\hline No. & Validator & $\begin{array}{c}\text { Score } \\
\text { Average }\end{array}$ & Criteria \\
\hline 1. & Sunaryo & 4.18 & Feasible \\
2. & Retno Kuntari & 4.59 & Very Feasible \\
3. & Heri Permana Sakti & 4.41 & Very Feasible \\
\hline & Score Average & 4.39 & Very Feasible \\
\hline
\end{tabular}

Based on table 2 and table 4 , the average scores of student worksheets are 4.43 and 4.36 , and they are very feasible. It means the criteria of development student worksheets are very eligible for three material aspects and five media aspects. Based on table 3 and table 5, the average scores of student worksheets are 4.49 and 4.39 , and they are very feasible. Based on those tables, it can be concluded that the student worksheet development is very eligible for both material and media aspects.

The product practical level is assessed by X IPA 1 students of SMA Negeri 1 Turi and X IPA students of SMA Islam 3 Sleman. There are 33 respondents consisting of 26 students of SMA Negeri 1 Turi, and the rest are students of SMA Islam 3 Sleman. The practical data analysis consists of the assessment of every aspect of development student worksheet and analysis of the average score from all respondents. The data analysis can be seen in Tables 6-8:
Table 6. Practical Data Result of Student Worksheet by Students

\begin{tabular}{cccc}
\hline No. & Respondent & $\begin{array}{c}\text { Score } \\
\text { Average }\end{array}$ & Criteria \\
\hline 1. & $\begin{array}{c}\text { Students of SMA } \\
\text { Negeri 1 Turi } \\
\text { Students of SMA Islam } \\
\text { 3 Sleman }\end{array}$ & 4.18 & Feasible \\
2. & 4.47 & Very Feasible \\
\hline & Score Average & 4.33 & Very Feasible \\
\hline
\end{tabular}

Table 7. Practical Data Result of Every Aspect in Student Worksheet by SMA Negeri 1 Turi Students

\begin{tabular}{cccc}
\hline No. & Aspect & $\begin{array}{c}\text { Score } \\
\text { Average }\end{array}$ & Criteria \\
\hline 1. & The Compatibility and & 4.18 & Feasible \\
2. & Ease & 4.33 & Very Feasible \\
3. & Conspicuousness & 4.14 & Feasible \\
4. & Clarity & 4.23 & Very Feasible \\
5. & Completeness & 3.90 & Feasible \\
6. & Exactibity and & 4.29 & Very Feasible \\
\hline & Motivation & 4.18 & Feasible \\
\hline
\end{tabular}

Table 8. Practical Data Result of Every Aspect in Student Worksheet by SMA Islam 3 Sleman Students

\begin{tabular}{cccc}
\hline No. & Aspect & $\begin{array}{c}\text { Score } \\
\text { Average }\end{array}$ & Criteria \\
\hline 1. & The Compatibility and & 4.52 & Very Feasible \\
2. & Ease & 4.57 & Very Feasible \\
3. & Conspicuousness & 4.26 & Very Feasible \\
4. & Clarity & 4.52 & Very Feasible \\
5. & Completeness & 4.64 & Very Feasible \\
6. & Exactiness & 4.50 & Very Feasible \\
\hline & Motivation & 4.50 & Very Feasible \\
\hline
\end{tabular}

Based on table 6 , the average score of development student worksheets from all respondents is 4.33 , and it is very feasible, which means the eligibility level of student worksheets from the practical aspect is very high. Based on table 7 , the average score of development student worksheet is 4.18 , and it is feasible, which means the student worksheet is feasible for 6 aspects by the assessment of X IPA 1 students of SMA Negeri 1 Turi. Based on table 8 , the average score of development student worksheet is 4.50 , and it is very feasible, which means the student worksheet is very feasible for 6 aspects by the assessment of X IPA students of SMA Islam 3.

Student worksheet products consist of various types and have become teaching materials that are commonly used in schools, so student worksheet is very diverse. The difference between this student worksheet product and the student worksheet product results [16], [17], and [18] is the content of HOTS questions, whereas the research products [16], [17] and [18] do not contain HOTS questions. Besides, the those products are still design. One example of HOTS problems contained in the worksheet products of this study can be seen in Figure 2: 


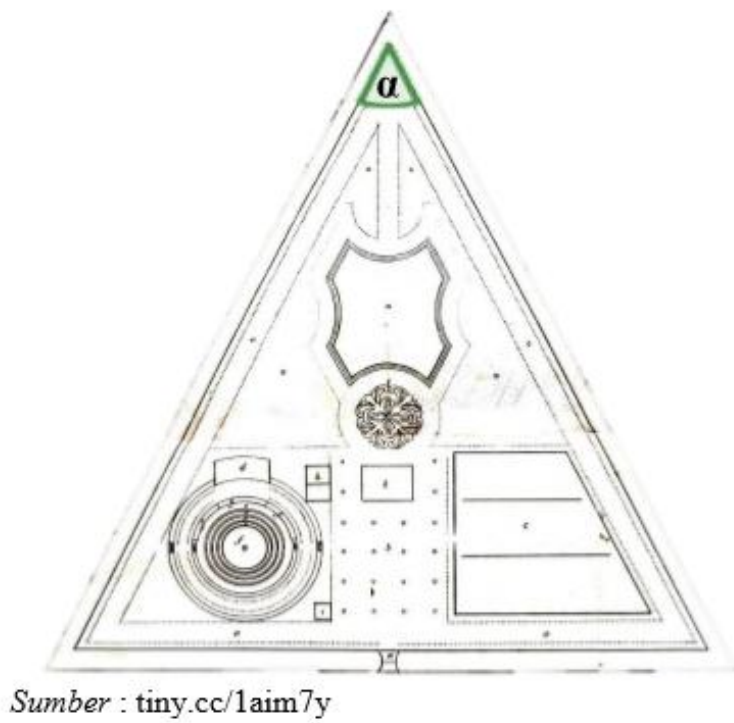

Gambar 1.15. Rancangan Taman

Rancangan taman di atas berbentuk segitiga sama kaki dengan besar sudut puncaknya yaitu $\alpha$.

Jika panjang kaki-kaki rancangan taman tersebut adalah $x \mathrm{~cm}$ dan panjang alas rancangan taman tersebut adalah $a \mathrm{~cm}$, maka tentukan perbandingan nilai $a$ dan $x$ agar luas rancangan taman tersebut maksimum!

Figure 2. The Example of HOTS Problem In The Student Worksheet

\section{Conclusions and Implementation}

This research is R\&D kind research, and the purposes of this research are to develop and test the eligibility of HOTS-based student worksheets with discovery learning. The student worksheets are developed by using a modified 4D development model and based on the researcher's needs. Based on the analysis data of media, mathematic material, and practical aspects, development student worksheets is very feasible. It explains that the development of student worksheets can be used as a teaching aid in the learning process. This research might be a reference for the development of a similar product. The purposes of this research are to develop and test the eligibility level of development products, so the researcher suggests to measure its effectiveness in the learning process.

The researcher recommends this worksheet for the teacher in order to enhance students HOTS. It will be even better if the teacher uses the discovery learning model in the learning process.

\section{REFERENCES}

[1] G.A.M. Saido, S. Siraj, A.B. Nordin, O.S. Al-Amedy, Teaching Strategies for Promoting Higher-order Thinking Skills: A Case of Secondary Science Teachers, Malaysian
Online Journal of Educational Management, University of Malaya, Vol.3, No.4, 16-30, 2015.

[2] M. Hugerat, Naji Kortam, Improving Higher Order Thinking Skills Among Freshmen by Teaching Science Through Inquiry, Eurasia Journal of Mathematics, Vol.10, No.5, 447-454, 2014.

[3] E. Apino, H. Retnawati, Developing Instructional Design to Improve Mathematical Higher-order Thinking Skills of Students, Journal of Physics: Conference Series, Universitas Negeri Yogyakarta, 2017.

[4] P. Budsankom, T. Sawangboon, S. Damrongpanit, J. Chuensirimongkol, Factors Affecting Higher-order Thinking Skills of Students: A Meta-Analytic Structural Equation Modeling Study. Academic Journals, Vol.10, No.19, 2639-2652, 2015.

[5] A.J. Canas, P. Reiska, A. Mollits, Developing higher-order thinking skills with concept mapping: A case of pedagogic frailty, Knowledge Management \& E-Learning: An International Journal, Vol.9, No.3, 348-365, 2017.

[6] T.S. Yen, S.H. Halili, Effective Teaching of Higher-Order Thinking (HOT) in Education, The Online Journal of Distance Education and e-Learning, Vol.3, No.2, 41-47, 2015.

[7] R. Verdina, Improving students' higher-order thinking skills in thermochemistry concept using worksheets based on 2013 curriculum, Journal of Physics: Conference Series. Aceh, Universitas Syiah Kuala. 2018.

[8] Kiki. Yuliani, S. Saragih, The Development of Learning Devices Based Guided Discovery Model to Improve 
Understanding Concept and Critical Thinking Mathematically Ability of Students at Islamic Junior High School of Medan, Journal of Education and Practice, Vol.6, No.24, 116-128, 2015

[9] E. Ellizar, Development of Scientific Approach Based on Discovery Learning Module, IOP Conference Series: Materials Science and Engineering, Padang, Universitas Negeri Padang, 2018.

[10] D.M. Putri, Suparman, Design of RME-Based Nathematical Module Development in Improving Problem Solving Ability, International Journal of Scientific \& Technology Research, Vol. 8, No. 10, 3629-3634, 2019.

[11] D. Istriani, Suparman, Student's Worksheet Design to Improve Problem Solving Ability for Tenth Grade with PBL, International Journal of Scientific \& Technology Research, Vol. 8, No.10, 1159-1163, 2019.

[12] E. Supriyadi, Suparman, Design Problem Based Student Worksheet to Improve Student Problem Solving Abilities Indonesia, International Journal of Scientific \& Technology Research, Vol. 8, No.10, 3064-3069, 2019.

[13] M.N. Pratiwi, Suparman, Mathematical Module Design to Improve Creative Thinking Skills Based on Problem Based Learning, International Journal of Scientific \& Technology Research, Vol. 8, No.10, 3761-3765, 2019.

[14] T. Badengo, Suparman, Design Module of Learning with RME Approach to Improve Creative Thinking Ability, International Journal of Scientific \& Technology Research, Vol. 8, No.10, 1178-1182, 2019.

[15] P. Nurafiati, 4D Model on Assessing Psychomotor Aspect in Continental Food Processing Practice, IOP Conference Series: Materials Science and Engineering, Bandung, Universitas Pendidikan Indonesia, 2018.

[16] Y.A. Wardani, Suparman, Student Learning Worksheet Design Based On STAD To Improve Mathematical Communication Skills, International Journal of Scientific \& Technology Research, Vol. 8, No.12, 2523-2527, 2019.

[17] P. Angraini, Suparman, Students Worksheet Design On Geometry For Seventh Grade Students With Rme Approach, International Journal of Scientific \& Technology Research, Vol. 8, No.10, 1155-1158, 2019.

[18] F.W. Mujahidah, Suparman, Student's Worksheets Design For Eighth Grade To Improve Problem-Solving Ability With RME, International Journal of Scientific \& Technology Research, Vol. 8, No.11, 2093-2098, 2019. 